\title{
The effect of process parameters in Aluminum Metal Matrix Composites with Powder Metallurgy
}

\author{
Vemula Vijaya Vani and Sanjay Kumar Chak ${ }^{*}$ \\ Division of Manufacturing Process and Automation Engineering, Netaji Subhas Institute of Technology, New Delhi 110078, India
}

Received: 15 November 2017 / Accepted: 18 January 2018

\begin{abstract}
Metal Matrix Composites are developed in recent years as an alternative over conventional engineering materials due to their improved properties. Among all, Aluminium Matrix Composites (AMCs) are increasing their demand due to low density, high strength-to-weight ratio, high toughness, corrosion resistance, higher stiffness, improved wear resistance, increased creep resistance, low co-efficient of thermal expansion, improved high temperature properties. Major applications of these materials have been in aerospace, automobile, military. There are different processing techniques for the fabrication of AMCs. Powder metallurgy is a one of the most promising and versatile routes for fabrication of particle reinforced AMCs as compared to other manufacturing methods. This method ensures the good wettability between matrix and reinforcement, homogeneous microstructure of the fabricated MMC, and prevents the formation of any undesirable phases. This article addresses mainly on the effect of process parameters like sintering time, temperature and particle size on the microstructure of aluminum metal matrix composites.
\end{abstract}

Keywords: aluminum matrix composites / particle size ratio / microstructure

\section{Introduction}

Metal matrix composites are gaining their applications in the last two decades due to their improved physical and mechanical properties and developed an alternative to procure materials with high stiffness. Among which aluminum matrix composites are gaining their advantage due to low density, high toughness and corrosive resistance [1]. This causes them to be preferred engineering materials for aerospace, military, automobiles and mineral processing industries. Silicon Carbide ( $\mathrm{SiC}$ ) and Alumina Oxide $\left(\mathrm{Al}_{2} \mathrm{O}_{3}\right)$ are commonly used reinforcement materials for automobile applications, such as diesel engine pistons, piston rings, connecting rods, drive shafts, brake disc, cylinder liners etc. [2]. SiC is widely used due to physical and chemical compatibility with Alumina (Al) matrix in wide range of available grades. Apart from this, $\mathrm{SiC}$ contributes an increase in young's modulus and tensile strength of the composite, and also $\mathrm{SiC}$ addition promotes an increase in wear resistance of the composites [3]. After $\mathrm{SiC}, \mathrm{Al}_{2} \mathrm{O}_{3}$ is widely used reinforcement, which promotes better corrosion and high temperature resistant behavior. The uniform distribution of particles into the matrix without agglomeration, with minimum interfacial reactions is the challenging task in fabrication of particulate

\footnotetext{
* e-mail: sanjaykchak@gmail.com
}

reinforced metal matrix composites [4]. Aluminum Metal Matrix Composites (AMMCs) are fabricated by liquid state fabrication methods (Stir casting, compo-casting, squeeze casting, spray casting and in-situ (reactive) processing, solid state fabrication methods (Powder Metallurgy, friction stir processing, diffusion bonding and vapour deposition technique) and deposition processes. This classification is based on the temperature of the matrix during the fabrication [5]. The difficulties associated with liquid state processing techniques are difficulties in mixing of two phases, proper wettability at the matrix and reinforcement interface, harmful interfacial reactions due to high processing temperatures [6]. The main pitfall in deposition technique is a time-consuming process, only be used with discontinuous reinforcement. The limitations in casting process is agglomeration of reinforcement and unwanted interfacial reactions, this is mainly due to higher processing temperatures [7-9]. The problems associated with above mentioned processes have been successfully overcome by powder metallurgy during the last decade. The advantages of powder metallurgy over other process like the problem of interfacial reactions, this can be achieved due to very low processing temperatures of the process. This paper reviews the effect of the different process parameters of powder metallurgy while developing the aluminum matrix composites. How the different process parameters like ball milling speed and time, compaction pressure, sintering time and temperature, size 


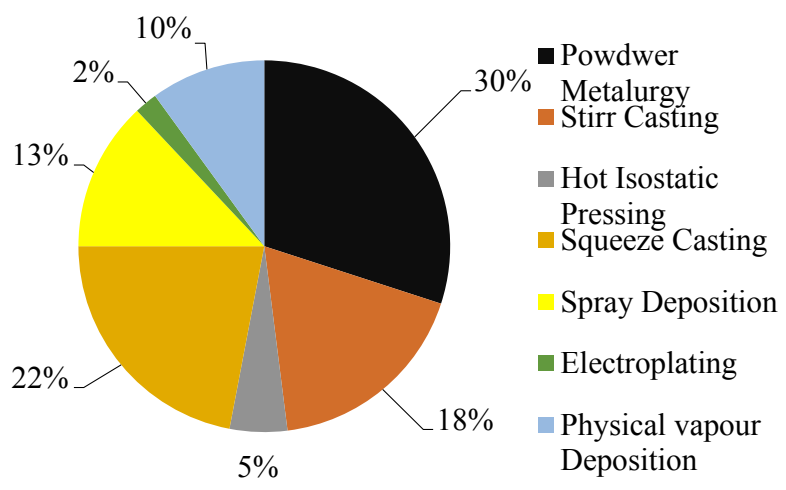

Fig. 1. Research Studies conducted on fabrication routes of MMCs for the last 10 years [11].

and percentage of reinforcement influences the microstructure of the composite.

\section{Fabrication of $A M M C s$ through various techniques}

Fabrication of metal matrix composites with uniformity in distribution of reinforcement into matrix is a challenging work. The commonly used fabrication methods are:

- solid state processing;

- liquid state processing.

The properties of ceramic reinforced composites are mainly depends on the properties of the matrix material, mutual wettability at the interface, size and volume percentage of the reinforcement particle [10]. The important parameters need to be considered in fabrication of MMCs are; matrix temperature during processing, extent and reinforcement loading and desired degree of micro structural integrity, because most of the mechanical properties of the composites are depends on the composition, matrix and reinforcement particle size and shape, volume fraction, reinforcement distribution and processing method which is used for fabrication, homogeneity between matrix and reinforcement [11]. Some of the factors are controllable like composition of the matrix, size and shape of the reinforcement, other factors like homogeneity of reinforcement distribution, are depends on the fabrication technique [12]. Figure 1 shows the different fabrication techniques used for metal matrix composites in the last ten years. It is observed that powder metallurgy is the most versatile method among other techniques.

The important features of different methods, for the fabrication of MMCs have been discussed in Table 1. The main drawbacks with liquid phase techniques are the agglomeration and dendritic segregation; it formed due to non-uniform distribution of ceramic particles in metallic matrix, while high temperature of the melt causes undesirable chemical reaction at the interface. Table 2 discusses different routes for processing of MMCs, cost involved and their applications. It reveals that powder metallurgy is the most suitable method for fabrication of MMC, as no interfacial reactions is formed in between matrix and reinforcement.

\section{Powder metallurgy}

Powder metallurgy is a metal processing technology in which parts are produced from metallic powders by following the sequence of operations, the powders are compressed into desired shape and then heating to temperature below the melting point to cause solid state bonding of the particles into a hard-rigid mass called sintering. The main advantage of powder metallurgy is that the matrix and reinforcement are mixed in the solid state which overcomes the problem of non-wetting between the reinforcements and liquid metal and preventing the formation of any undesirable phases. Table 3 reveals that, in the powder metallurgy process, it is possible to achieve uniform distribution of reinforcement in to the matrix and better control of micro structure, unlike in other fabrication processes of MMCs, where agglomeration of particles is the main problem in the fabrication of particulate reinforced metal matrix composites.

From the Table 3, it clearly reveals that powder metallurgy method gives the excellent uniformity in microstructure of the composite when compared with other manufacturing techniques like Co-Spray, Rheocasting and liquid infiltration methods. Compared to other manufacturing techniques like ingot pressing and diffusion welding, powder metallurgy offer some advantages due to low manufacturing temperatures that diminishes the interfacial reactions between the matrix and reinforcement $[9,14]$. This can be achieved due to solid state diffusion of inter particle bonding, whereas the diffusion bonding plays a major role in controlling the microstructure and mechanical properties of the compact [15-17].

The Reinforcement particle size and shape plays a major role in the fabrication. In powder metallurgy most widely reinforcement particles used are in the form of particles and whiskers [9]. The commonly used matrix materials for aluminum based composite materials are listed below in Table 4.

\section{Effect of the processes and parameters}

\subsection{Powder blending}

Blending of ceramic particles with matrix is a key step of powder metallurgy, as it facilitates the uniformity in the shapes of powder particles, controls the final distribution of the reinforcement particles and porosity in green compacts after compaction [8]. Proper blending of matrix and ceramic powders reduces the agglomeration of the powder particles. Over mixing leads to reduction in flow characteristic of the mix, leading to poor homogeneity in particle distribution. Table 5 represents the blending time and speed for different AlMMCs while performing blending operation. Before blending (or) mixing, the parameters

mainly need to consider are reinforcement shape and size, volume percentage, blending time and speed. Slipenyuk et al. [12], reported that matrix to particle size ratio (PSR) should be near to 1 which leads to finer micro structure and better mechanical properties. They have also reported that if the PSR is larger than this value, which 
Table 1. MMC fabrication categories [11].

\begin{tabular}{|c|c|c|}
\hline Composite type/Process & $\begin{array}{c}\text { Examples (Reinforcement/ } \\
\text { Matrix) }\end{array}$ & Main features \\
\hline \multicolumn{3}{|l|}{ Solid state processing } \\
\hline $\begin{array}{l}\text { In-situ forming - internal } \\
\text { oxidation } \\
\text { Powder forming }\end{array}$ & $\begin{array}{l}\mathrm{Al}_{2} \mathrm{O}_{3} / \mathrm{SiO}_{2} \mathrm{BeO} \text { particulate } \\
\text { in } \mathrm{Cu} \text { or } \mathrm{Ag}\end{array}$ & $\begin{array}{l}\text { Modest strength strength improvement } \\
\text { Good electrical conductivity }\end{array}$ \\
\hline Sintered aluminum powder & $\mathrm{Al}_{2} \mathrm{O}_{3}$ particulate/Al matrix & $\begin{array}{l}\text { Moderate strength and stiffness around } 300^{\circ} \mathrm{C} \\
\text { Low density }\end{array}$ \\
\hline $\begin{array}{l}\text { Long or short fibers or } \\
\text { particulate incorporated by } \\
\text { powder metallurgy }\end{array}$ & & $\begin{array}{l}\text { Good stiffness/strength to modest particulate } \\
\text { incorporated temperatures } \\
\text { Low density } \\
\text { Low thermal expansion }\end{array}$ \\
\hline Mechanical alloying & $\begin{array}{l}\text { Oxide particles in super alloy } \\
\text { matrix }\end{array}$ & $\begin{array}{l}\text { High performance alloy } \\
\text { High strength at high temperatures }\end{array}$ \\
\hline $\begin{array}{l}\text { Diffusion bonding } \\
\text { Long fibers in intermetallic } \\
\text { Liquid state processing }\end{array}$ & $\mathrm{SiC}$ fibers in $\mathrm{Ti}_{3} \mathrm{Al}$ etc. & Some problems over oxidation at high temperatures \\
\hline Molten metal mix processing & $\begin{array}{l}\mathrm{SiC}_{\text {or }} \mathrm{Al}_{2} \mathrm{O}_{3} / \text { Light alloy } \\
\text { matrices }\end{array}$ & Modest improvements in properties \\
\hline Infiltration of performs & $\begin{array}{l}\mathrm{SiC} \text { whiskers, } \mathrm{Al}_{2} \mathrm{O}_{3} \text { fibers } / \mathrm{Al} \\
\text { alloys } \mathrm{C} / \mathrm{Al} \text { and } \mathrm{Mg} \text { alloys } \\
\mathrm{SiC} / \mathrm{Ti} \text { alloys } \mathrm{B} / \mathrm{Al} \text { alloys }\end{array}$ & $\begin{array}{l}\text { Good stiffness and strength to } 200^{\circ} \mathrm{C} \\
\text { Low density } \\
\text { Low thermal conductivity }\end{array}$ \\
\hline $\begin{array}{l}\text { Dispersion Semi solidus } \\
\text { processing }\end{array}$ & $\begin{array}{l}\text { Various ceramic dispersoids } \\
\text { into the melt } \mathrm{Si} \text { in } \mathrm{Al}\end{array}$ & $\begin{array}{l}\text { Some problems in controlling the microstructure } \\
\text { Modest strength } \\
\text { Good wear characteristics }\end{array}$ \\
\hline Spraying & $\begin{array}{l}\text { Particulate/short or long } \\
\text { fibers in alloy matrices, for } \\
\text { example, } \mathrm{Sic} \text { or } \mathrm{Al}_{2} \mathrm{O} / \text { in } \mathrm{Al} \\
\text { alloys }\end{array}$ & $\begin{array}{l}\text { Good stiffness and strength } \\
\text { Low density } \\
\text { Low thermal expansion coefficient }\end{array}$ \\
\hline $\begin{array}{l}\text { In situ processing } \\
\text { Other techniques }\end{array}$ & $\mathrm{TiB}_{2}$ particulate/ $\mathrm{Al}$ alloy & $\begin{array}{l}\text { Good strength ductility and toughness } \\
\text { Fatigue resistant }\end{array}$ \\
\hline Molecular level mixing & $\begin{array}{l}\text { Carbon nano tubes }(\mathrm{CNTs}) \\
\text { reinforced copper }(\mathrm{Cu}) \text { matrix } \\
\text { nano composites }\end{array}$ & $\begin{array}{l}\text { No clustering of molecules } \\
\text { Uniform dispersion }\end{array}$ \\
\hline $\mathrm{CIP}+\mathrm{HIP}$ & $\mathrm{TiC}_{\mathrm{p}}$ particulate/Al alloy & $\begin{array}{l}\text { Formation of oxidation constraint of high temperature } \\
\text { use }\end{array}$ \\
\hline Sputtering method & $\begin{array}{l}\text { Titanium aluminide alloy, } \\
\text { Ti-Al-Nb, on short length } \\
\text { Sic fibers }\end{array}$ & $\begin{array}{l}\text { Microstructure modification } \\
\text { Clean environment with excellent impurity control } \\
\text { Good repeatability/reproducibility } \\
\text { Homogeneity of the deposited matrix }\end{array}$ \\
\hline
\end{tabular}

results in formation of agglomeration due to reduction in the surface area of the matrix, which is insufficient for a uniform arrangement of reinforcement particles [12]. Segregation of the particles is the major problem that occurs in blending process, it depends on the flow characteristics between metal powders and reinforcement particles, and tendency of the clustering of particles to minimize their surface energy [25]. The flow characteristics of the particles can be improved by adding lubricants like zinc stearate (or) stearic acid in 0.25 to $5 \mathrm{wt} \%$. Particles are taken in different forms like spherical, rounded, irregular, porous and angular. The shape of the particles depends on the powder production method. Figure 2 shows the Monte Carlo simulations of shaking species, which indicated the segregation behavior of the particles. As shown in Figure 2 the larger particles raised to the top of the container and helps in filling the voids at the bottom of the larger particles and which is majorly depends on the number of cycles applied on the container $[24,25]$. The densities of matrix and reinforcement powder particles also plays a major role 
Table 2. Comparision of MMCs techniques [13].

\begin{tabular}{|c|c|c|c|}
\hline Route & Cost & Applications & Comments \\
\hline $\begin{array}{l}\text { Liquid-metal } \\
\text { infiltration }\end{array}$ & Low/medium & $\begin{array}{l}\text { Used to produce structural shapes } \\
\text { such as rods, tubes, beams with } \\
\text { maximum properties in a uniaxial } \\
\text { direction }\end{array}$ & Filaments of reinforcement used \\
\hline Squeeze casting & Medium & $\begin{array}{l}\text { Widely used in automotive industry } \\
\text { for producing different components } \\
\text { such as pistons, connecting rods, } \\
\text { rocker arms, cylinder heads, suitable } \\
\text { for making complex objects }\end{array}$ & $\begin{array}{l}\text { Generally applicable to any type of } \\
\text { reinforcement and may be used for large scale } \\
\text { manufacturing }\end{array}$ \\
\hline Spray casting & Medium & $\begin{array}{l}\text { Used to produce friction materials, } \\
\text { electrical brushes and contacts, } \\
\text { cutting and grinding tools }\end{array}$ & $\begin{array}{l}\text { Particulate reinforcement used: full density } \\
\text { materials can be produced }\end{array}$ \\
\hline $\begin{array}{l}\text { Compocasting/ } \\
\text { rheocasting }\end{array}$ & Low & $\begin{array}{l}\text { Widely used in automotive, } \\
\text { aerospace, industrial equipment and } \\
\text { sporting goods industries, used to } \\
\text { manufacture bearing materials }\end{array}$ & $\begin{array}{l}\text { Particulate reinforcement used: full density } \\
\text { materials can be produced. Suitable for } \\
\text { discontinuous fibers especially particulate } \\
\text { reinforcement }\end{array}$ \\
\hline
\end{tabular}

Table 3. Relative characteristics of a different manufacturing processes [18].

\begin{tabular}{lllll}
\hline \multirow{1}{*}{ Attributes } & \multicolumn{4}{c}{ Processes } \\
\cline { 2 - 5 } & $\begin{array}{l}\text { Powder } \\
\text { metallurgy }\end{array}$ & $\begin{array}{l}\text { Co- } \\
\text { Spray }\end{array}$ & $\begin{array}{l}\text { Rheo- } \\
\text { casting }\end{array}$ & $\begin{array}{l}\text { Liquid } \\
\text { infiltration }\end{array}$ \\
\hline Microstructure & 1 & 2 & 2 & 2 \\
$\begin{array}{l}\text { Semi continuous } \\
\text { process }\end{array}$ & 3 & 1 & 1 & 4 \\
$\begin{array}{l}\text { Low Potential } \\
\text { Cost }\end{array}$ & 4 & 2 & 1 & 2 \\
Industrial Maturity & 1 & 2 & 2 & 4 \\
\hline
\end{tabular}

1: Excellent. 2: Very good. 3: Good. 4: Average

in blending, such as lighter particles remains at the top whereas the heavier particles try to segregate at the bottom $[7,26]$.

The blending time plays a major role. Razavi et al. [28] states that by adding hard ceramic reinforcement like $\mathrm{Al}_{2} \mathrm{O}_{3}$ in to soft metallic matrix like $\mathrm{Al}$, the fracture occurs earlier and thus the steady state condition is achieved in shorter ball milling time. Ball milling is the versatile method used for blending of metal powders. For $\mathrm{Al} / \mathrm{CNT}$ a new ball milling technique is used called as Shift Speed Ball Milling, which is a combination of powder mixing at two different speeds, the milling process with lower speeds are called Low Speed Ball Milling, whereas milling process with high speed is called High Speed Ball Milling [29]. For Al/ CNT composites, shift speed ball milling technique was used for uniform dispersion of CNT in Al matrix. Run et al. [29], observed that at longer starting low speed ball milling (LSBM) and a shorter following high speed ball milling (HSBM) achieve amalgamate CNT dispersion and interfacial bonding achieved. In the process of blending or mixing of particles with the ball milling process, alumina powder particle deformation occurs in three stages. Firstly, flattened into flakes, secondly cold welded into tiny particle and lastly fragmented into smaller particles. In the process of blending for CNTs were also dispersed on the surface of alumina flakes in the first step, in second step CNTs are occluded by alumina and finally CNTs are trapped into the cold welded particles [30-32].

\subsection{Powder compaction}

The principle objective of compaction process is to apply pressurize and bond the particles to form a cohesion among the powder particles. This is usually called green compact. For a good compaction, irregular shaped particles are preferred as they give better interlocking and hence high green strength. The indispensable amount of pressure depends upon the initial shape of the matrix and reinforcement, the matrix and reinforcement material, the method of blending and application of lubricants, additives and desired density of green compact. Compacting aluminum based composites requires less force (about $200 \mathrm{MPa}$ ), because high compressibility of aluminum powders. Table 6 represents amount of compaction 
Table 4. Matrices of Aluminum alloy based composite materials.

\begin{tabular}{lll}
\hline Alloy designation & Chemical composition & Literature \\
\hline 2014 & Al-5.0\%Cu-0.7\%Mn-0.7\%Si-0.5\%Fe-0.4\%Mg & {$[19]$} \\
& Al-4.0\%Cu-1.5\%Mg-0.5\%Mn-0.3\%Fe & {$[19,20]$} \\
6711 & Al-1.0\%Mg-0.7\%Fe-0.6\%Si-0.25\%Zn & {$[20,21]$} \\
7075 & Al-1.0\%Mg-0.8\%Si-0.25 Cu & {$[22]$} \\
8090 & Al- $5.5 \%$ zn- $2.5 \% \mathrm{Mg}-1.5 \% \mathrm{Cu}-0.4 \% \mathrm{Si}-0.3 \% \mathrm{Cr}$ & {$[23]$} \\
\hline
\end{tabular}

Table 5. Process parameters for different MMCs while performing blending operation.

\begin{tabular}{lllll}
\hline S.No. & \multicolumn{1}{c}{ Composition type } & \multicolumn{1}{c}{ Blending time $(\mathrm{hr})$} & Blending speed $(\mathrm{rpm})$ & References \\
\hline 1 & $\mathrm{Al}-\mathrm{Al}_{2} \mathrm{O}_{3}$ & 2 & 150 & {$[33]$} \\
2 & $\mathrm{Al}-\mathrm{SiC}-\mathrm{B}_{4} \mathrm{C}$ & 12 & 200 & {$[34]$} \\
3 & $\mathrm{Al}-\mathrm{Zr}$ based glassy reinforcement & 1 & 150 & {$[35]$} \\
4 & $\mathrm{Al}-\mathrm{Al}_{2} \mathrm{O}_{3}$ & 24 & 150 & {$[14,36]$} \\
5 & $\mathrm{Al}-\mathrm{Si} / \mathrm{SiC}$ & 0.5 & 50 & {$[2]$} \\
6 & $6711 \mathrm{Al}-\mathrm{SiC}$ & 8 & - & {$[22]$} \\
7 & $\mathrm{Al} / \mathrm{CNT}$ & 1 & $135(\mathrm{LSBM})$ & {$[29]$} \\
8 & $\mathrm{FeCo}-\mathrm{CNT}$ & 30 min & $270(\mathrm{HSBM})$ & {$[37]$} \\
9 & $\mathrm{Al} / \mathrm{CNT}$ & 120 & $250(\mathrm{HSBM})$ & {$[38]$} \\
10 & $\mathrm{Al} / \mathrm{CNT}$ & Varying time up to $48 \mathrm{~h}$ & $450(\mathrm{HSBM})$ & {$[31]$} \\
\hline
\end{tabular}

Table 6. Compaction pressure for different MMCs.

\begin{tabular}{llll}
\hline S.No. & Metal matrix composites & Compaction pressure $(\mathrm{MP})$ & References \\
\hline 1 & $\mathrm{Al} / 10 \mathrm{wt} \% \mathrm{SiC}-\mathrm{Cu}$ & 180 & {$[39]$} \\
2 & $(3 N i+\mathrm{Fe})-\mathrm{Al}_{2} \mathrm{O}_{3}$ & 750 & {$[40]$} \\
3 & $\mathrm{SiC}_{\mathrm{p}} / \mathrm{Al}-10 \mathrm{wt} \% \mathrm{Si}$ and & 30 at $540-570^{\circ} \mathrm{C}$ (Hot pressed) & {$[2]$} \\
& $\mathrm{SiC}_{\mathrm{p}} / \mathrm{Al}-12 \mathrm{wt} \% \mathrm{Si}$ & & {$[41]$} \\
4 & $\mathrm{Al} / \mathrm{SiC}$ & $200-300$ & {$[33]$} \\
5 & $\mathrm{Al} / \mathrm{Al}_{2} \mathrm{O}_{3}$ & 440 & {$[22]$} \\
6 & $6711 \mathrm{Al} / \mathrm{SiC}$ & 400 & {$[42]$} \\
7 & $\mathrm{Cu}-\mathrm{graphite}_{3}$ & 700 & {$[43]$} \\
8 & $\mathrm{Al} / \mathrm{SiC}_{\mathrm{p}}$ & 80 ton & {$[44]$} \\
9 & $\mathrm{Al} / \mathrm{SiC}_{\mathrm{p}}$ & 200 & {$[34]$} \\
10 & $\mathrm{Al}-\mathrm{SiC}-\mathrm{B}_{4} \mathrm{C}$ & 150 & {$[45]$} \\
\hline
\end{tabular}

pressure for different materials for different applications. The different compaction methods are reported like cold, warm (or) hot isostatic pressing (HIP) $[7,26]$ for achieving good quality of green compact with desired green strength and density. The Table 6 shows the compaction pressure for different MMCs.

\subsection{Sintering temperature}

The main mechanism involved in sintering is the green compact is heated just above the melting temperature of the matrix, the matrix powder melts and reacts with other elements i.e reinforcement in the powder mixture to form a 


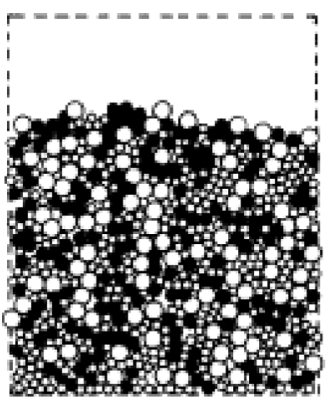

(a)

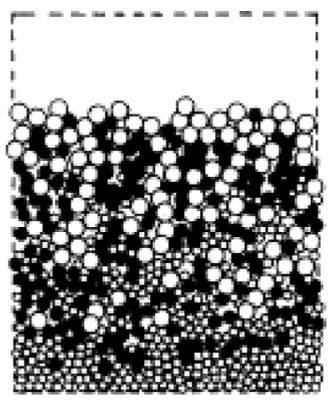

[b]

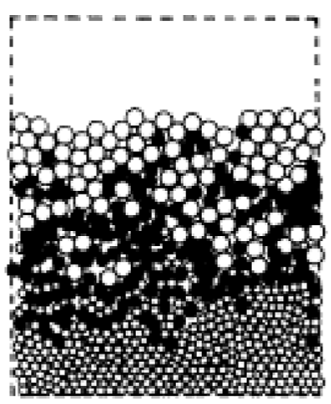

$\mid$ |c|

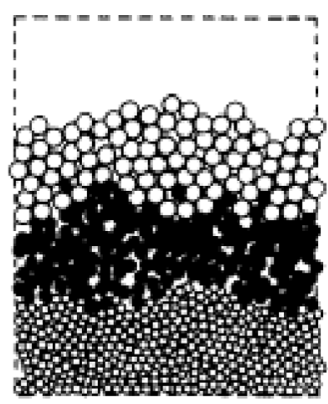

(d)

Fig. 2. Configurations at (a) 0, (b) 60, (c) 120 and (d) 290 cycles from Monte Carlo Simulations of the shaking of a ternary mixture of particles: the shaking amplitude is equal to the diameter of smallest particles [27].

Table 7. Sintering time, temperature for different MMCs.

\begin{tabular}{lllll}
\hline S.No. & \multicolumn{1}{c}{ Composite } & Sintering time $(\mathrm{min})$ & Sintering temperature $\left({ }^{\circ} \mathrm{C}\right)$ & Reference \\
\hline 1 & $\mathrm{Al} / \mathrm{SiC}_{\mathrm{p}}$ & 45 & 620 & {$[44]$} \\
2 & $\mathrm{Al}-\mathrm{SiC}-\mathrm{B}_{4} \mathrm{C}$ & 15 & 610 & {$[34]$} \\
3 & $\mathrm{Al}-\mathrm{Al}_{2} \mathrm{O}_{3}$ & 45 & 550 & {$[36]$} \\
4 & $\mathrm{Al}-\mathrm{Al}_{2} \mathrm{O}_{3}$ & $30-90$ & $500-600$ & {$[14]$} \\
5 & $\mathrm{SiC} / \mathrm{Cu}-\mathrm{Al}$ & 120 & $650-800$ & {$[39]$} \\
6 & $6711 \mathrm{Al} / \mathrm{SiC}$ & - & 1040 & {$[22]$} \\
7 & $\mathrm{NiFe}-\mathrm{CNT}$ and $\mathrm{Ni3Fe}-\mathrm{CNT}$ & 60 & & {$[45]$} \\
\hline
\end{tabular}

liquid between the particles that engulfs the more refractory phase [46]. The Table 7 , shown below gives how much sintering time and temperature has been considered by the researchers for sintering process for fabrication of AlMMCs.

The two main stumbling blocks may arise in fabrication of MMCs. One is due to numerous reinforcement phase ( $\mathrm{SiC}$ ) are thermodynamically unreliable in matrix (e.g $\mathrm{Al}$ ) $[47,48]$, which leads to interfacial reactions (Tab. 8). The second difficulty is due to difference in thermal expansion coefficients between the ceramic reinforcement and metallic matrix. For instance, coefficient of thermal expansion for $\mathrm{Al}$ is $24 \times 10^{-6} \mathrm{~K}^{-1}$ whilst it is only $3.8 \times 10^{-6} \mathrm{~K}^{-1}$ for $\mathrm{SiC}$. This causes the thermal mismatch strain over the reinforcement and matrix interface while cooling in processing of MMC. The associated strain is then sufficient to generate local plastic yield in the Al matrix [49]. If the MMC is then subjected to thermal cycling, microstructural/sub structural damage can accumulate leading instability or under low loads to accelerated creep which amounts to superplastic behavior [50].

The main controlling factor in sintering is sintering temperature [51] The selection of sintering temperature plays a major role. The Figure 3 shows the morphology of $\mathrm{Al} / \mathrm{SiC}-\mathrm{Cu} \mathrm{MMC}$ at different temperatures. At temperature $650{ }^{\circ} \mathrm{C}$ in Figure 3a, distinct $\mathrm{SiC}$ grains primarily discover at the grain boundary, under the microscope it reveals that a transient layer is separating $\mathrm{SiC}$ and $\mathrm{Al}$ matrix. Al melts above $660^{\circ} \mathrm{C}$ and flow to cover the Sic $-\mathrm{Cu}$ ceramic reinforcement. At $700^{\circ} \mathrm{C}$ in Figure $3 \mathrm{~b}$ very thin grain boundary is developed between the two adjacent $\mathrm{Al}$ grains and $\mathrm{SiC}$ is distributed homogeneously in the developed boundary or grown $\mathrm{Al}$ grains. As the temperature is increased to $750{ }^{\circ} \mathrm{C}$, the wider grain boundary is developed as compared in Figure 3c, so that SiC particles present both at the grain boundary and in the inner of $\mathrm{Al}$ grains. At temperatures $800^{\circ} \mathrm{C}$ in Figure $3 \mathrm{~d}$, at high temperatures the reduction in surface tension of molten $\mathrm{Al}$ is observed and viscous flow is increased. Some $\mathrm{SiC}$ grains form an intra-granular grains in the $\mathrm{Al}$ matrix, rest $\mathrm{SiC}$ grains separate from the melting $\mathrm{Al}$ or $\mathrm{Cu}$ due to poor wettability between each other, leads to heterogeneous microstructure shown in Figure 3d [39]. Baghchesara et al. [52] studied micro structure and mechanical properties of nano $\mathrm{MgO}$ reinforced $\mathrm{Al}$ matrix $\mathrm{MMCs}$, and they states that at higher sintering temperatures leads to increasing wettability of matrix and reinforcement by improving the interfacial bonding between the nano $\mathrm{MgO}$ particles and $\mathrm{Al}$ matrix.

The sintering temperature plays a major role in the structure of the composites, at higher sintering temperatures a close compact structure is obtained due higher diffusion rates $[14,53]$.

This can be clearly understood by equation (1)

$$
D=D_{0} \exp \left(\frac{-Q}{R T}\right),
$$

where $D$ is diffusion coefficient, $D_{0}$ is constant, $Q$ is activation energy, $R$ is Boltzmann's constant and $T$ is temperature.

The main stumbling block in solid state sintering is the ceramic reinforcement phase reduces the compressibility of aluminum alloy powders [54] and affects the sintering stress 
Table 8. Examples of interactions in selected fiber matrix system [47].

\begin{tabular}{|c|c|c|}
\hline System & Interaction & Approx. temp. of significant interaction $\left({ }^{\circ} \mathrm{C}\right)$ \\
\hline $\mathrm{C}-\mathrm{Al}$ & Formation of $\mathrm{Al}_{4} \mathrm{C}_{3}$ & 550 \\
\hline $\mathrm{C}(\mathrm{I})-\mathrm{Ni}$ & Fiber recrystallization activated by $\mathrm{Ni}$ & $1150-1300$ \\
\hline $\mathrm{C}(\mathrm{II})-\mathrm{Ni}$ & Fiber recrystallization activated by $\mathrm{Ni}$ & 800 \\
\hline $\mathrm{B}-\mathrm{Al}$ & Formation of bordies & 500 \\
\hline $\mathrm{SiC}-\mathrm{Al}$ & Formation of $\mathrm{TiB}_{2}$ & 750 \\
\hline $\mathrm{B}-\mathrm{Ti}$ & $\begin{array}{l}\text { No significant reaction below melting point } \\
\text { (Formation of Al4C } 3 \text { ) }\end{array}$ & m.pt 660 \\
\hline $\mathrm{Sic}-\mathrm{Ti}$ & $\mathrm{TiSi}, \mathrm{Ti}_{5} \mathrm{Si}_{3}$ and $\mathrm{TiC}$ form & 700 \\
\hline $\mathrm{SiC}-\mathrm{Ni}$ & Formation of nickel silicides & 800 \\
\hline $\mathrm{Al}_{2} \mathrm{O}_{3}-\mathrm{Al}$ & No significant reaction & - \\
\hline \multirow[t]{2}{*}{$\mathrm{Al}_{2} \mathrm{O}_{3} \mathrm{Ni}$} & $\mathrm{Al}, \mathrm{O}$ dissolution(very little) gives pits & 1100 \\
\hline & In air, $\mathrm{NiAl}_{2} \mathrm{O}_{4}$ formation & 1100 \\
\hline $\mathrm{W}-\mathrm{Cu}$ & No interaction upto melting point & m.pt 1083 \\
\hline \multirow[t]{2}{*}{$\mathrm{W}-\mathrm{Ni}$} & Recrystallization of fiber & 1000 \\
\hline & Degredation of creep properties & 900 \\
\hline $\mathrm{W}-\mathrm{Fe}$ & Formation of $\mathrm{Fe}_{7} \mathrm{~W}_{6}$; dissolution of fiber & 1000 \\
\hline Steel-Al & $\mathrm{Fe}_{2} \mathrm{Al}_{5}$ formation & 500 \\
\hline Tac-Co & Dissolution(dissolution/reprecipitation) & 1200 \\
\hline
\end{tabular}
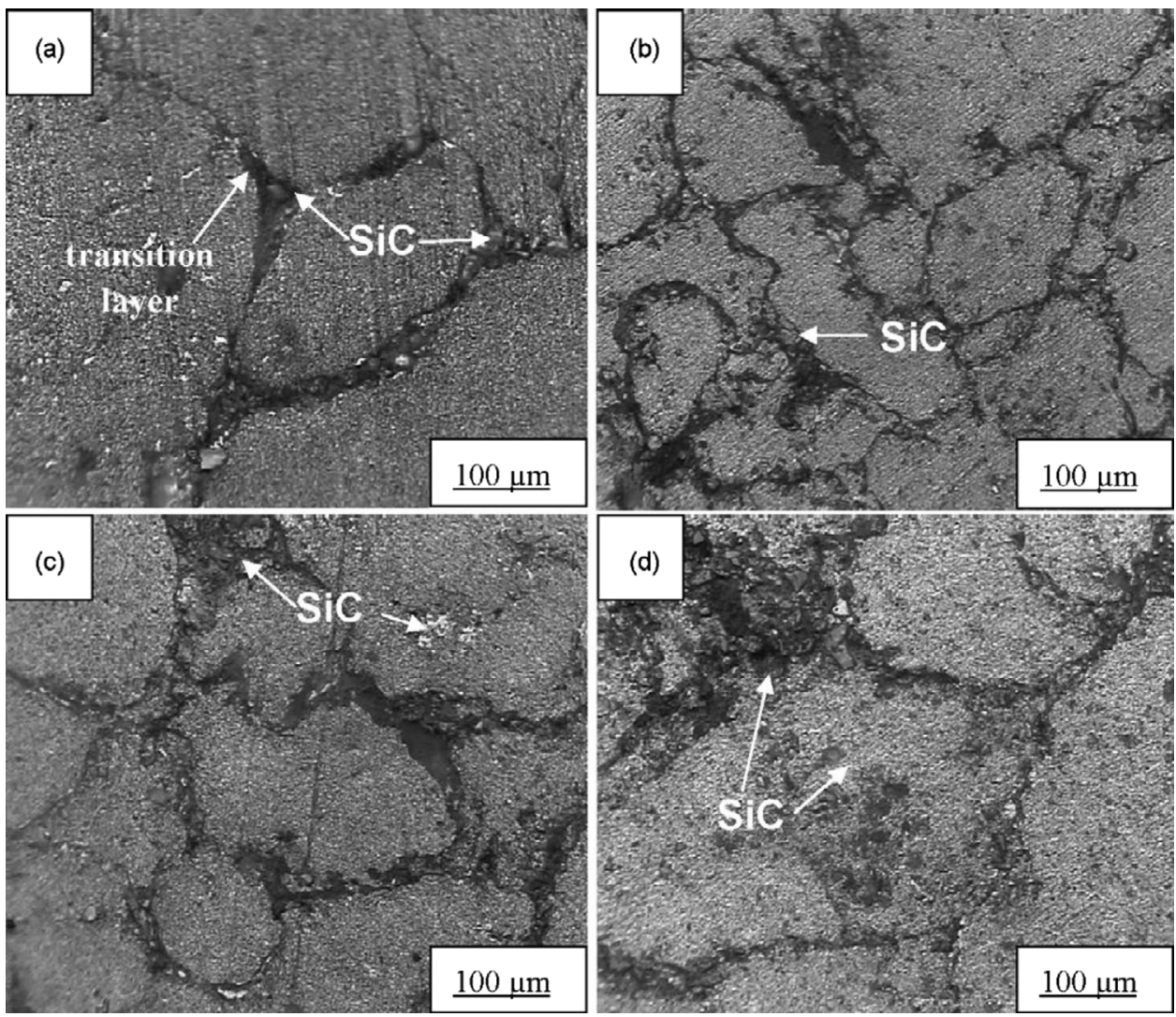

Fig. 3. Morphology of $\mathrm{SiC} / \mathrm{Cu}-\mathrm{Al}$ composite sintered at different temperatures: (a) $650{ }^{\circ} \mathrm{C}$ (b) $700^{\circ} \mathrm{C}$ (c) $750{ }^{\circ} \mathrm{C}(\mathrm{d}) 800^{\circ} \mathrm{C}[62]$.

at $\mathrm{Al}-\mathrm{Al}$ contacts, causes poor bonding between matrix and reinforcement phase $[55,56]$. Super solidus Liquid Sintering (SLPS) differs from liquid phase sintering is, in which, pre-alloyed powders are heated between the solidus and liquidus temperatures of the alloy [57]. In case of MMC reinforced with Carbon Nano Tubes, Spark Plasma Sintering (SPS) technique was used to facilitate more effective interfacial bonding with less reactions [37].The 
conventional sintering technique is accompanied with limitations, e.g. long sintering time may lead to a grain growth, which may be overcome with spark plasma sintering. This novel technique prepares composites with high densities with relatively low sintering times [58-60]. Ridvan et al. [61] stated that in spark plasma sintering of Al-nano $\mathrm{SiC}$ composite, the sintering temperature plays vital role in densification of composites. They concluded that the spark is generated at the interface of matrix and reinforcement, originating temperature rise at the contact point and eutectic melting occurring along the particle boundaries resulting in higher relative density. Another sintering technique is called field assisted sintering (also called spark plasma sintering) in which low voltage (typically $10 \mathrm{~V}$ ) and high current density (typically $1-$ $10 \mathrm{kA}$ ) were used. Pressure assisted process with short sintering cycles leads to increase in productivity [62]. In Liquid phase sintering, matrix liquid phase coexists with a particulate solid reinforcement at the sintering temperature which helps to improve inter particle bonding between the matrix and the reinforcement. A proper inter particle bonding in composite is necessary for better mechanical properties like strength, magnetic and corrosive properties. Compared to other sintering processes, liquid sintering process is a fast sintering process providing the fast atomic diffusion. The capillary attraction is phenomena, due to wetting liquid, leading to rapid compact densification without need of application of external pressure. The liquid phase also helps in reducing inter particle friction, by aiding rapid rearrangement of solid particles. Also liquid phase sintering enables efficient packing by liquid dissolution of sharp particle edges and corners. During liquid phase sintering grain size control is also possible, thus, helping manipulation of the microstructure in order to optimize the properties $[63,64]$.

\subsection{Sintering time}

The diffusion in conventional sintering process depends on the sintering time. This can be clearly explained by equation (2) [65].

$$
r=2.4 \sqrt{D t}
$$

where $r$ is the radial distance, $D$ is the diffusion coefficient and $t$ is the diffusion time.

Figure 3 depicts that the radial distance is directly proportional to square root of the sintering time which is responsible for the atomic diffusion leading to finer grain structure. Figure 4 depicts that elongation percentage increases at higher sintering time. The effect of higher sintering time on grain growth along with elongation is shown in Figure 5 [66].

\subsection{The effect of particle size on microstructure}

The size and volume percentage, distribution of reinforcement in the metallic matrix, plays a vital role in the microstructure and properties of the metal matrix composites.

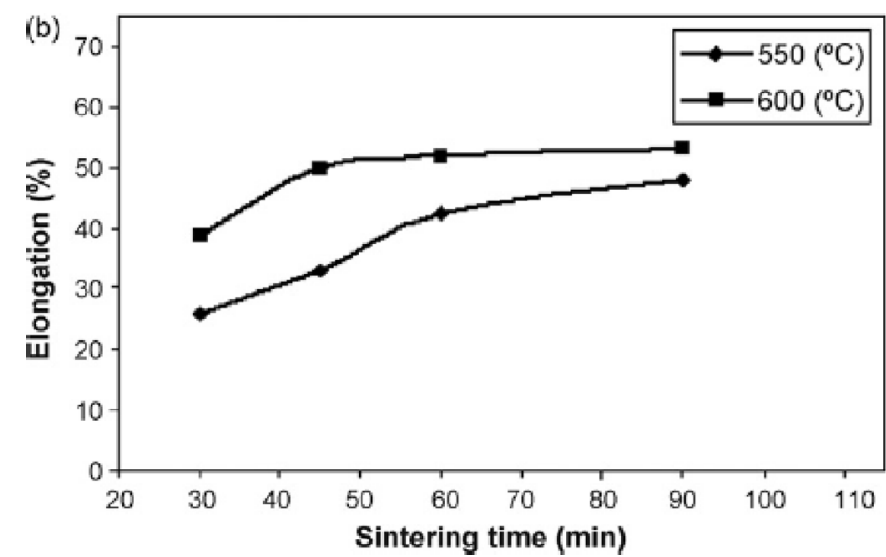

Fig. 4. Variation of the elongation to fracture of the composites $\left(\mathrm{Al}-\mathrm{Al}_{2} \mathrm{O}_{3}\right)$ as a function of sintering time [13].
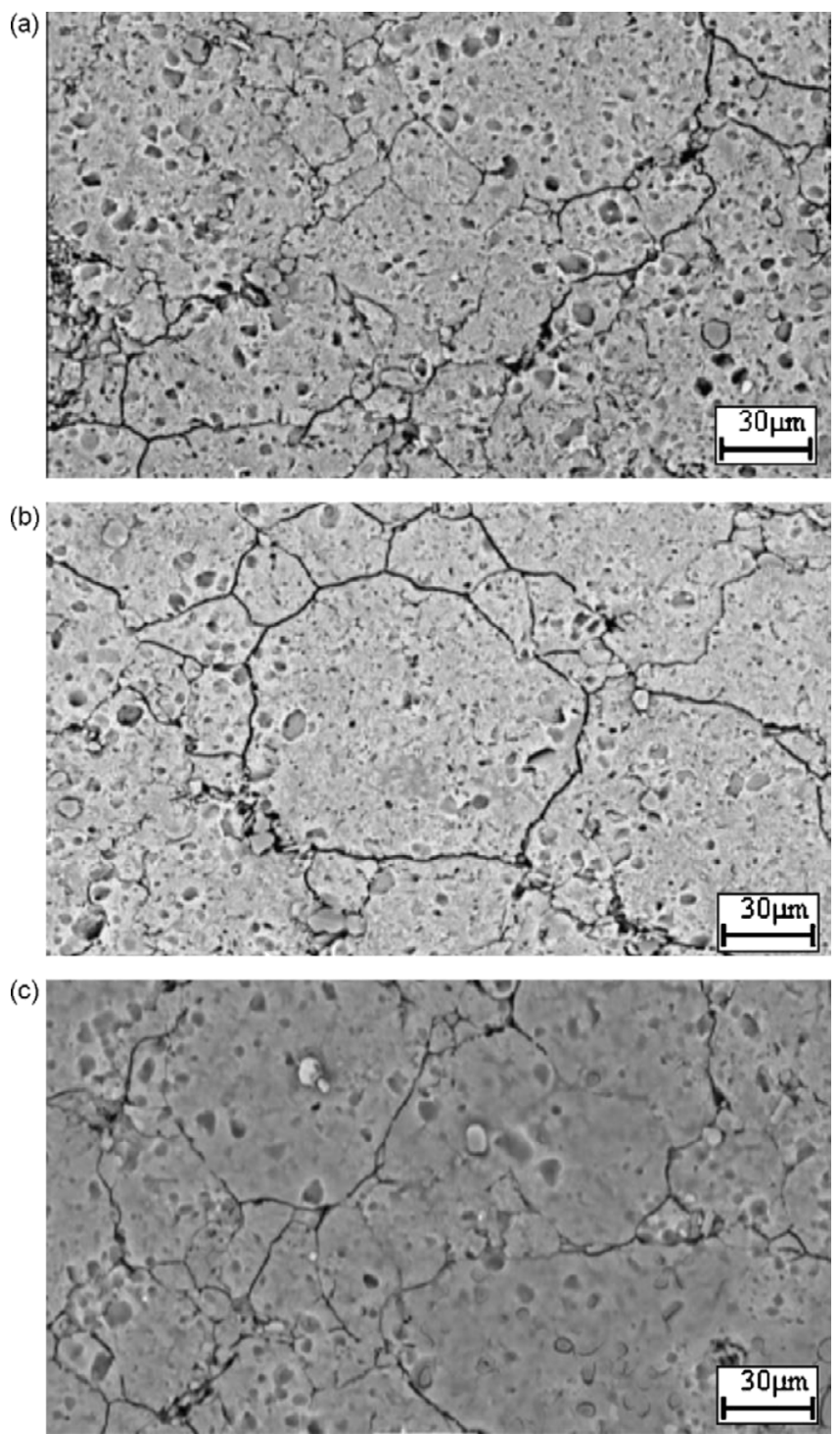

Fig. 5. The effect of sintering time on microstructure of the composites at $600{ }^{\circ} \mathrm{C}$ (a) 40 (b) 60 and (c) $90 \mathrm{~min}$ [61]. 
Table 9. Variation of Microstructure grain size and area as function of particle size and content of $\mathrm{Al}_{2} \mathrm{O}_{3}$ [60].

\begin{tabular}{llll}
\hline Alumina particle size $(\mu \mathrm{m})$ & Alumina content $(\mathrm{wt} \%)$ & Grain size number ASTME112-96 & Grain ${\operatorname{area~}\left(\mu \mathrm{m}^{2}\right)}^{2}$ \\
12 & 5 & 7.4 & 1100 \\
12 & 10 & 8.7 & 730 \\
12 & 20 & 9.2 & 288 \\
3 & 10 & 9.5 & 236 \\
48 & 10 & 7.8 & 1004 \\
\hline
\end{tabular}

The variation in grain structure is discussed in Table 9. As the volume percentage of the alumina particle increases, finer structure is produced. This is due to the alumina particles act as a barriers to the movement of grain boundaries and hence delay for the grain growth [36]. Padmavathi et al. [22] states that up to $10 \mathrm{vol} \%$ of $\mathrm{SiC}$ reinforcement in $6711 \mathrm{Al}$ alloy results uniform distribution of of $\mathrm{SiC}$ particles throughout the matrix, as the $\mathrm{SiC}$ percentage increases beyond $10 \mathrm{vol} \%$ resulted cluster formation. Upto optimum percentage of reinforcement into metallic matrix gives homogeneous microstructure.

This is explained with the following equation (3)

$$
\lambda=\frac{4(1-f) r}{3 f},
$$

where $f$ is the volume fraction of the reinforcement, and its radius $r, \lambda$ is the inter particle distance [67].

The strength of the composites increases with increase in volume fraction of reinforcement and decreasing as increase in particle size of the reinforcement [68]. This means that the mechanical properties of the composites like hardness, yield strength, compressive strength and elongation to fracture were higher when the particle size is fine as compared to coarse particle size of the reinforcement. The particle size of the reinforcement and matrix plays an important role, because it is difficult to force hard ceramic particles into a soft metallic matrix. Therefore, the uniformity of dispersion depends upon the particle size of the matrix and reinforcement, the particle size ratio (PSR) closer to one yields a more homogeneous microstructure [69]. Particle to matrix size ratio increases, leads to increase in the cluster formation. Researchers are using nano size reinforcements,

Figure $6 \mathrm{a}$ and $\mathrm{b}$ clearly shows that they have good homogeneity in the structure, where as in Figure $6 c$ and d formation of clusters is more due to high PSR [12]. At larger particle size ratio, low combined surface area of the matrix and reinforcement particles leads to the formation of clusters of $\mathrm{SiC}$ particles in between the larger $\mathrm{Al}$ alloy particles [12].

Figure 7 shows the surface of the composites of different PSRs after extrusion. Figure 7a shows the surface free from cracks compared to the surface shown in Figure 7b, where as in Figure 7c, d depict observable cracks on the surface, this is due to larger particle size ratios (PSRs) in samples c and d. Stone and Tsakiropoulis [70] concluded that this cracks on the surface is due to formation of voids into which the matrix could not flow.
Thus, the selection of proper size of reinforcement and matrix alloy is a very crucial point to achieving homogeneous distribution of reinforcement into metallic matrix. The nano-size particles are mixed between the aluminum powder particles, during blending and compaction. Other extrusion processes are not suitable for breaking the $\mathrm{SiC}$ clusters completely to achieve uniform distribution of the nano-particles in the metal matrix composites. Previous studies have reported that mechanical properties were degraded due to agglomeration of $\mathrm{SiC}$ particles in $\mathrm{Al}$ matrix, and this agglomeration also lead to formation of clustering along with voids in the particles. These formations may lead to crack propagation and stress transformation from the soft matrix to the hard reinforcement [71-75]. The relation between inter particle spacing size and volume fraction of the reinforcement is as follows:

$$
\lambda=d_{r}\left[\left(\frac{\pi}{6 V_{f}}\right)^{\frac{1}{3}}-1\right],
$$

where $d_{r}$ represents the reinforcement size, and $\lambda$ represents the inter-particle spacing.

From above relation 4 , it is clear that the inter particle spacing varies inversely with the reinforcement volume fraction and directly proportional to the reinforcement size [68], shown in Figure 8.

The uniformity in the distribution of the reinforcement is anticipated only when the reinforcement size $d_{r}$ is not less than a critical value $d_{c}$

$$
\begin{gathered}
d_{r} \geq d_{c}, \\
d_{c}=\frac{d_{m}}{\left[\left(\frac{\pi}{6 V_{f}}\right)^{\frac{1}{3}}-1\right] \sqrt{R}} .
\end{gathered}
$$

In the above equation, the critical value is a function of matrix powder size $d_{m}$, volume fraction of reinforcement particles $\left(V_{f}\right)$ and reduction ratio $(R)$ in secondary process [68].

The reduction ratio for Extrusion process is:

$$
\frac{d_{m}}{d_{f}}=\sqrt{R}
$$

where $d_{m}$ and $d_{f}$ are original and final transverse length of the matrix powder. 


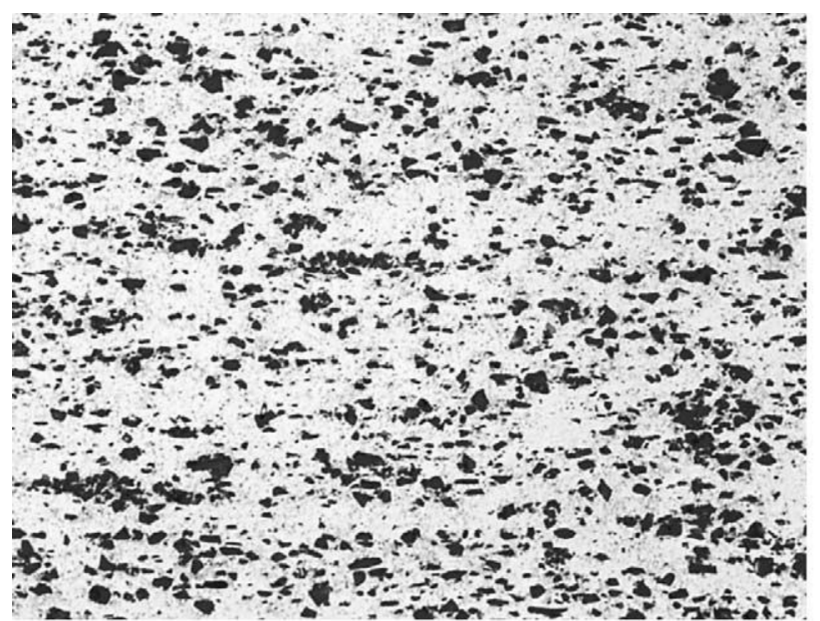

(a)

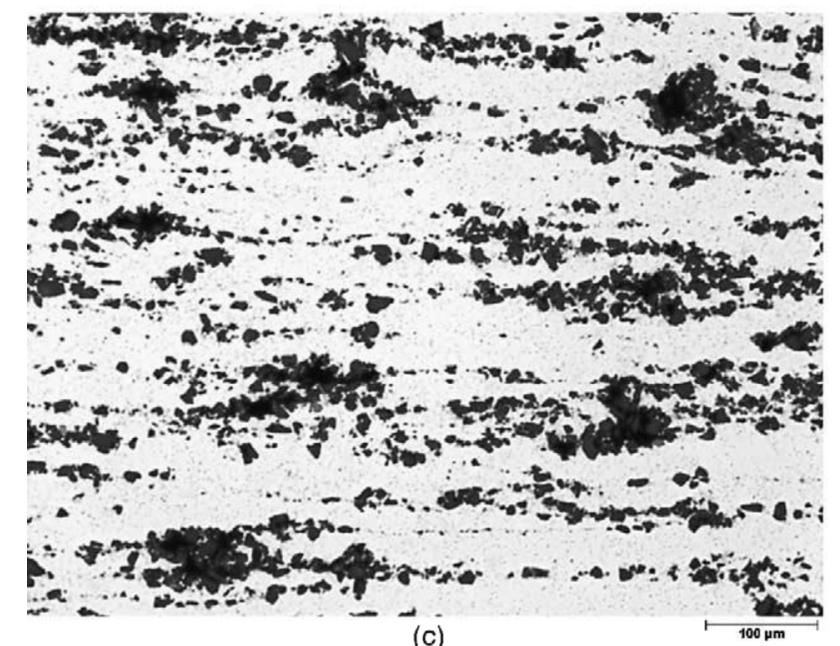

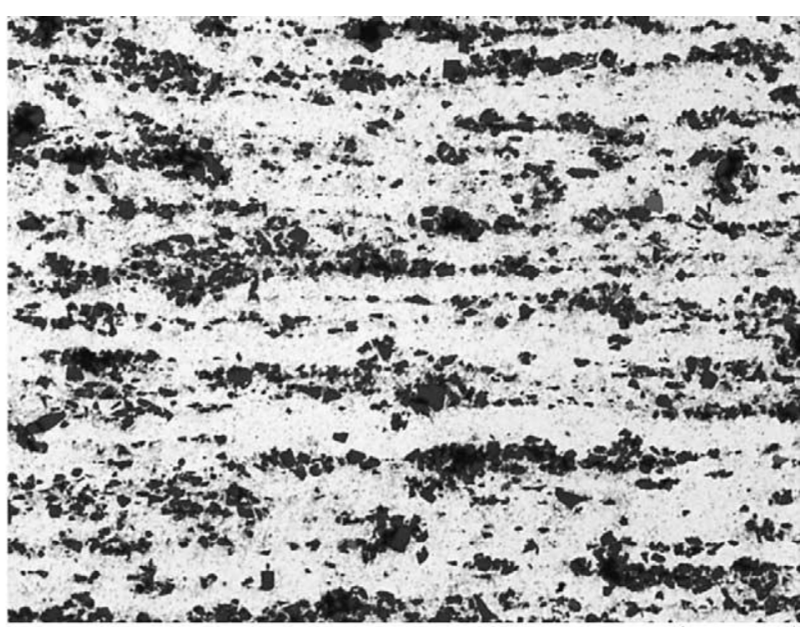

(b)

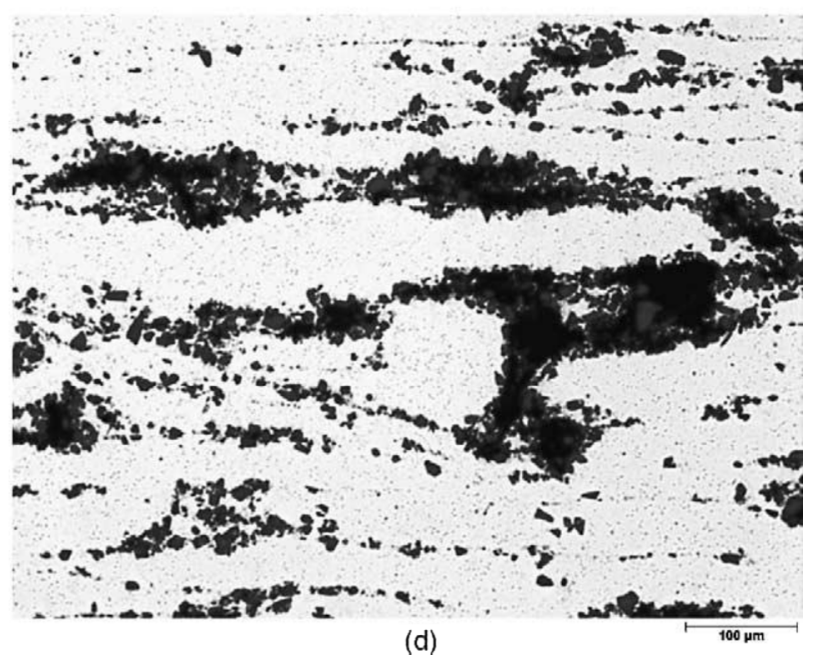

(d)

Fig. 6. Reinforcement distribution in the composites prepared using powders with various matrix to reinforcement particle size ratios. (a) 2.9 ; (b) 5.7 ; (c) 9.3 ; (d) 12.9 [12].

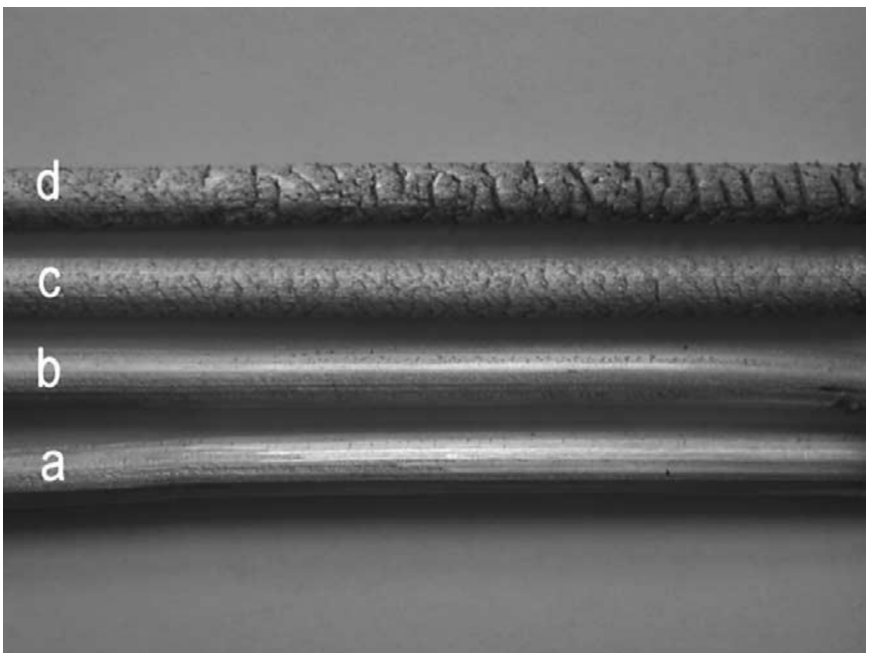

Fig. 7. Surface view of the extruded composite samples prepared using powders with various PSRs: (a) 2.9; (b) 5.7 ; (c) 9.3 ; (d) 12.9 [12].

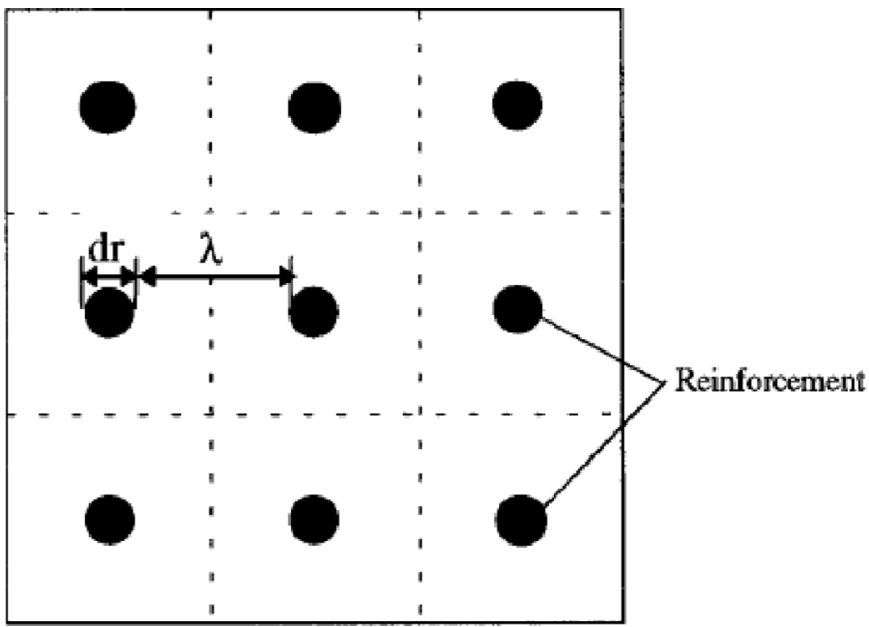

Fig. 8. Schematic illustration of spherical reinforcement under ideally homogeneous distribution condition [60]. 
The reduction ratio for rolling process is:

$$
R \prime=\frac{h_{0}-h_{f}}{h_{0}},
$$

where $h_{0}$ and $h_{f}$ are original and final thickness of the specimen.

\section{Conclusion}

This article gives detailed information on how the process parameters may have effect on the microstructures of the Aluminum based composites. Powder metallurgy is one of the versatile methods for producing composites with homogeneous distribution of reinforcement into matrix with minimum interfacial reactions. This may be achieved by minimizing processing temperatures. The microstructure of the composites depends on the various factors, such as sintering time, sintering temperature, size and volume percentage of reinforcement.

- Higher sintering temperatures result in a higher diffusion rate, leading to a denser structure.

- Proper selection of reinforcement and matrix particle size plays a vital role for achieving uniform dispersion of reinforcement into the metallic matrix.

- Optimum percentage of reinforcement results in the finer microstructure, due to hard ceramic particles act as a barrier to the grain boundaries and hence, delays the grain growth.

This paper intends to suggest an idea for selecting reinforcement and particle size and selecting process parameters for achieving homogeneous structure of the composite. However, a number of challenges still exist in the fabrication of the metal matrix composites through powder metallurgy. Further research is needed on how to reduce porosity in the composite. It may be reduced to some extent by introducing nano reinforcement into the matrix. The nano particles could fill the gaps in the matrix which reduce the porosity of the composite. Research is also being conducted by introducing special sintering methods such as microwave sintering, laser and spark plasma sintering, to address similar issues.

\section{References}

1. M. Kok, Production and mechanical properties of Al2O3 particle-reinforced 2024 aluminium alloy composites, J. Mater. Process. Technol 161 (2005) 381-387

2. H.S. Lee, et al., The fabrication process and mechanical properties of $\mathrm{SiCp} / \mathrm{Al}-\mathrm{Si}$ metal matrix composites for automobile air-conditioner compressor pistons, J. Mater. Process. Technol. 113 (2001) 202-208

3. R. Zhang, L. Gao, J.K. Guo, Thermodynamic behaviour of copper-coated silicon carbide particles during conventional heating and spark plasma sintering, J. Am. Ceram. 86 (2003) 1446-1448

4. P. Rohatgi, R. Asthana, S. Das, Solidification, structures, and properties of cast metal-ceramic particle composites, Int. Met. Rev. 31 (1986) 115-139
5. G. Ramu, R. Bauri, Effect of equal channel angular pressing (ECAP) on microstructure and properties of Al-SiCp composites, Mater. Des. 30 (2009) 3554-3559

6. A.A. Mazen, A.Y. Ahmed, Mechanical behavior of Al-Al2O3 MMC manufactured by PM techniques part I-scheme I processing parameters, J. Mater. Eng. Perform. 7 (1998) 393401

7. I.A. Ibrahim, F.A. Mohamed, E.J. Lavernia, Particulate reinforced metal matrix composites - a review, J. Mater. Sci. 26 (1991) 1137-1156

8. Y.B. Liu, et al., Recent development in the fabrication of metal matrix-particulate composites using powder metallurgy techniques, J. Mater. Sci. 29 (1994) 1999-2007

9. J.M. Torralba, C.E. da Costa, F. Velasco, P/M aluminum matrix composites: an overview, J. Mater. Process. Technol. 133 (2003) 203-206

10. J.W. Kaczmar, K. Pietrzak, W. Włosinski, The production and application of metal matrix composite materials, J. Mater. Process. Technol. 106 (2000) 58-67

11. S. Preetkanwal, Fabrication and machining of metal matrix composites: a review, Mater. Manuf. Process. 31 (2016) 553573

12. A. Slipenyuk, et al., The effect of matrix to reinforcement particle size ratio (PSR) on the microstructure and mechanical properties of a $\mathrm{P} / \mathrm{M}$ processed $\mathrm{AlCuMn} / \mathrm{SiCp}$ MMC, Mater. Sci. Eng. A 381 (2004) 165-170

13. M. Schwartz, Composite materials: processing fabrication and applications, II, Prentice Hall PTR, 1997

14. M. Rahimian, et al., The effect of particle size, sintering temperature and sintering time on the properties of $\mathrm{Al}-\mathrm{Al} 2 \mathrm{O} 3$ composites, made by powder metallurgy, J. Mater. Process. Technol. 209 (2009) 5387-5393

15. R.M. German, Powder metallurgy of iron and steel, Wiley, USA, 1998

16. A.K. Bodukuri, et al., Fabrication of Al-SiC-B4C metal matrix composite by powder metallurgy technique and evaluating mechanical properties, Perspect. Sci. 8 (2016) 428-431

17. H.S. Chen, et al., Microstructure evolution and mechanical properties of $\mathrm{B} 4 \mathrm{C} / 6061 \mathrm{Al}$ neutron absorber composite sheets fabricated by powder metallurgy, J. Alloy. Compd. 730 (2018) 342-351

18. A. Feest, Metal powder report, (1992) 4045

19. M. Vedani, E. Gariboldi, Damage and ductility of particulate and short-fibre Al Al2O3 composites, Acta Mater. 44 (1996) 3077-3088

20. J. Jiang, B. Dodd, Workability of aluminium-based metalmatrix composites in cold compression, Composites 26 (1995) $62-66$

21. K. Asano, Properties of squeeze cast Al-bas composite materials strenthened with delta alumina fibers, Proceedings of 19th Congress of International Council for the Aeronautical Sciences, 2, 1994, 1814-1823

22. A.U. Padmavathi, Densification, microstructure and properties of supersolidus liquid phase sintered 6711 Al-Sic metal matrix composites, Sci. Sinter. 42 (2010) 363-382

23. T.J.A. Doel, P. Bowen, Tensile properties of particulatereinforced metal matrix composites, Compos. Part A: Appl. Sci. Manuf. 27 (1996) 655-665

24. B.Q. Han, K.C. Chan, Superplastic deformation mechanisms of particulate reinforced aluminium alloy matrix composites, Mater. Sci. Eng. 212 (1996) 256-264 
25. P.K. Rohatgi, S. Ray, Y. Liu, Tribological properties of metal matrix-graphite particle composites, Int. Mater. Rev. 37 (1992) 129-152

26. H.J. Rack, Fabrication of high performance powder-metallurgy aluminum matrix composites, Adv. Mater. Manuf. Process. 3 (1988) 327-358

27. A.D. Rosato, T. Vreeland, F.B. Prinz, Manufacture of powder compacts, Int. Mater. Rev. 36 (1991) 45-79

28. Z.R. Hesabi, A. Simchi, S.M.S. Reihani, Structural evolution during mechanical milling of nanometric and micrometric $\mathrm{Al} 2 \mathrm{O} 3$ reinforced Al matrix composites, Mater. Sci. Eng. A 428 (2006) 159-168

29. R. Xu, et al., Balanced strength and ductility in $\mathrm{CNT} / \mathrm{Al}$ composites achieved by flake powder metallurgy via shiftspeed ball milling, Compos. Part A: Appl. Sci. Manuf. 96 (2017) 57-66

30. C. Suryanarayana, Mechanical alloying and milling, Prog. Mater. Sci. 46 (2001) 1-184

31. A. Esawi, K. Morsi, Dispersion of carbon nanotubes (CNTs) in aluminum powder, Compos. Part A: Appl. Sci. Manuf. 38 (2007) 646-650

32. A.M.K. Esawi, et al., Fabrication and properties of dispersed carbon nanotube-aluminum composites, Mater. Sci. Eng. A 508 (2009) 167-173

33. M. Rahimian, N. Parvin, N. Ehsani, The effect of production parameters on microstructure and wear resistance of powder metallurgy Al-Al2O3 composite, Mater. Des. 32 (2011) 10311038

34. A.K. Bodukuri, et al., Fabrication of Al-SiC-B4C metal matrix composite by powder metallurgy technique and evaluating mechanical properties, Perspect. Sci. 8 (2016) 428-431

35. S. Scudino, et al., Mechanical properties of Al-based metal matrix composites reinforced with Zr-based glassy particles produced by powder metallurgy, Acta Mater. 57 (2009) 2029-2039

36. M. Rahimian, et al., The effect of sintering temperature and the amount of reinforcement on the properties of Al-Al2O3 composite, Mater. Des. 30 (2009) 3333-3337

37. A.J. Albaaji, et al., Effect of ball-milling time on mechanical and magnetic properties of carbon nanotube reinforced FeCo alloy composites, Mater. Des. 122 (2017) 296-306

38. E.I. Salama, A. Abbas, A.M.K. Esawi, Preparation and properties of dual-matrix carbon nanotube-reinforced aluminum composites, Compos. Part A: Appl. Sci. Manuf. 99 (2017) 84-93

39. H. Wang, et al., Characterization of a powder metallurgy $\mathrm{SiC} / \mathrm{Cu}-\mathrm{Al}$ composite, J. Mater. Process. Technol. 197 (2008) 43-48

40. V.G. Karayannis, A.K. Moutsatsou, Fabrication of MMCs from metal and alloy powders produced from scrap, J. Mater. Process. Technol. 171 (2006) 295-300

41. M. Rosso, Ceramic and metal matrix composites: Routes and properties, J. Mater. Process. Technol. 175 (2006) 364-375

42. C.P. Samal, J.S. Parihar, D. Chaira, The effect of milling and sintering techniques on mechanical properties of $\mathrm{Cu}$-graphite metal matrix composite prepared by powder metallurgy route, J. Alloy. Compd 569 (2013) 95-101

43. B. Venkatesh, Mechanical properties of metal matrix composites $\left(\mathrm{Al} / \mathrm{SiC}_{\mathrm{p}}\right)$ particles produced by powder metallurgy, Int. J. Eng. Res. Gen. Sci. 3 (2015)

44. V. Jeevan et al., Compaction, sintering and mechanical properties of $\mathrm{Al}-\mathrm{SiCp}$ composites, Int. J. Mech. Eng. Technol. 3 (2012) 565-573
45. S. Azadehranjbar, F. Karimzadeh, M.H. Enayati, Development of NiFe-CNT and Ni3Fe-CNT nanocomposites by mechanical alloying, Adv. Powder Technol. 23 (2012) 338342

46. H. Momeni, H. Razavi, S.G. Shabestari, Effect of supersolidus liquid phase sintering on the microstructure and densification of the $\mathrm{Al}-\mathrm{Cu}-\mathrm{Mg}$ prealloyed powder, Iran. J. Mater. Sci. Eng. 8 (2011) 10-17

47. S.I. Andersen, H. Lilholt, O.B. Pedersen, Mechanical and physical behaviour of metallic and ceramic composites, Proceedings of the 9th Ris $\varnothing$ International Symposium on Metallurgy and Materials Science, 5-9 September, Ris $\emptyset$ National Laboratory, 1988

48. D.J. Lloyd, H.P. Lagacé, A.D. Mcleod, Interfacial phenomena in metal matrix composites, in: H. Ishida (Ed.), Controlled Interphases in Composite Materials: Proceedings of the Third International Conference on Composite Interfaces (ICCI-III) held on May 21-24, Springer, Dordrecht, Netherlands 1990, pp. 359-376

49. R.J. Arsenault, N. Shi, Dislocation generation due to differences between the coefficients of thermal expansion, Mater. Sci. Eng. 81 (1986) 175-187

50. M.Y. Wu, O.D. Sherby, Superplasticity in a silicon carbide whisker reinforced aluminum alloy, Scr. Metall. 18 (1984) 773-776

51. R. German, Sintering theory and practice, Wiley, New York, 1996

52. M.A. Baghchesara, Microstructure and Mechanical Properties of Aluminium Alloy Matrix Composite Reinforced with Nano MgO Particles, Asian J. Chem. 22 (2010) 67696777

53. K.H. Min, et al., Sintering characteristic of Al2O3-reinforced 2xxx series Al composite powders, J. Alloy. Compd. 400 (2005) 150-153

54. J.B. Fogagnolo, et al., The effects of mechanical alloying on the compressibility of aluminium matrix composite powder, Mater. Sci. Eng. A 355 (2003) 50-55

55. V.V. Dabhade, T.R.R. Mohan, P. Ramakrishnan, Sintering behavior of titanium-titanium nitride nanocomposite powders, J. Alloy. Compd 453 (2008) 215-221

56. H. Asgharzadeh, A. Simchi, Supersolidus liquid phase sintering of Al6061/SiC metal matrix composites, Powder Metall. 52 (2009) 28-35

57. N. Showaiter, M. Youseffi, Compaction, sintering and mechanical properties of elemental $6061 \mathrm{Al}$ powder with and without sintering aids, Mater. Des. 29 (2008) 752-762

58. R. Yamanoglu, et al., Sintering and microstructure characteristics of $42 \mathrm{CrMo} 4$ steel processed by spark plasma sintering, Met. Mater. Int. 19 (2013) 1029-1034

59. R. Yamanoglu, W. Bradbury, E. Karakulak, E.A. Olevsky, R.M. German, Characterisation of nickel alloy powders processed by spark plasma sintering, Powder Metall (2014)

60. A. Teber, F. Schoenstein, F. Tetard, M. Abdellaoui, N. Jouini, Effect of SPS process sintering on the microstructure and mechanical properties of nanocrystalline $\mathrm{TiC}$ for tools application, J. Refract. Met. 30 (2012) 64-70

61. Y. Ridvan, E.A. Olevsky, Consolidation of Al-nanoSiC composites by spark plasma sintering, Int. J. Mater. Mech. Manuf. 4 (2016)

62. M. Suárez, A. Fernández, J.L. Menéndez, R. Torrecillas, H. U. Kessel, J. Hennicke, R. Kirchner, T. Kessel, Sintering applications, in: B. Ertu (Ed.), InTech, Croatia, 2013, pp.

63. R.M. German, Liquid phase sintering Plenum Press, New York, 1985, 4-5 p. 
64. G.B. Schaffer, T.B. Sercombe, R.N. Lumley, Liquid phase sintering of aluminium alloys, Mater. Chem. Phys. 67 (2001) 85-91

65. K.E. Esterling, Phase Transformations in metals and alloys, McGraw-Hill, New York, 1980

66. E. Saiz, A.P. Tomsia, K. Suganuma, Wetting and strength issues at $\mathrm{Al} / \alpha$-alumina interfaces, J. Eur. Ceram. Soc. 23 (2003) 2787-2796

67. G.E. Dieter, Mechanical metallurgy, 3rd edition, McGrawHill, 1976

68. X. Zhang, M.J. Tan, Selection of particulate reinforcement in $\mathrm{P} / \mathrm{M}$ metal matrix composites, J. Mater. Process. Technol. 63 (1997) 913-917

69. K.K.C. Nikhilesh Chawla, Metal matrix composites, Springer, New York, 2006, 88 p

70. P. Tsakiropoulous, Mater. Sci. Eng. A 189 (1994) 285

71. Z.W.H. Chao SunMin Song, Effect of particle size on the microstructures and mechanical properties of SiC-reinforced pure aluminum composites, J. Mater. Eng. Perform. 20 (2011) 1606-1612

72. N. Chawla, J.J. Williams, R. Saha, Mechanical behavior and microstructure characterization of sinter-forged SiC particle reinforced aluminum matrix composites, J. Light Met. 2 (2002) 215-227

73. A.V. Muley, S. Aravindan, I.P. Singh, Nano and hybrid aluminum based metal matrix composites: an overview, Manufacturing Rev. 2 (2015) 15

74. A.E. Nassar, E.E. Nassar, Properties of aluminum matrix Nano composites prepared by powder metallurgy processing, J. King Saud Univ. - Eng. Sci. 29 (2017) 295-299

75. A.V. Muley, S. Aravindan, I.P. Singh, Mechanical and tribological studies on nano particles reinforced hybrid aluminum based composite, Manufacturing Rev. 2 (2015) 26

Cite this article as: Vemula Vijaya Vani, Sanjay Kumar Chak, Effect of the process and parameters of powder metallurgy on the microstructures of aluminum metal matrix composites, Manufacturing Rev. 5, 7 (2018) 